УДК $35.082(477)$

DOI https://doi.org/10.32837/pyuv.v2i3(28).352

\author{
В. В. Васильківська \\ кандидат юридичних наук, \\ доиент кафедри адміністративного і фінансового права \\ Національного університету «Одеська юридична академія»
}

\title{
ОЦІНЮВАННЯ ДЕРЖАВНИХ СЛУЖБОВЦІВ: ОСОБЛИВОСТІ ФАКТОРІВ, ЩО ВПЛИВАЮТЬ НА РЕЗУЛЬТАТ
}

Звертаючи увагу на активні управлінські зміни на рівні органів публічного управління, а також стрімкі трансформаційні зміни у структуpi державних органів та установ, 3 упевненістю можна стверджувати, що реформи публічного управління є одними з основних для країни в умовах подолання кризи в економічній, соціальній та політичній сферах. Окрім того, пошук нових шляхів підвищення ефективності функціонування державної служби в цілому в Україні зумовлює концентрацію уваги зацікавленої спільноти на поглибленому дослідженні ресурсу тих інститутів, впровадження яких є нині нагальною потребою для наближення вітчизняних правових стандартів державної служби до європейських та міжнародно-правових аналогів та використання закордонного досвіду з метою удосконалення національних інституцій. Однією з таких актуальних сфер є оцінювання результатів службової діяльності державних службовців.

Треба відзначити, що нині оцінювання діяльності державних службовців в Україні є однією з тих процедур управління людськими ресурсами, яка має суттєвий потенціал для впливу на публічне адміністрування загалом, його характер, у тому числі ефективність та прозорість управління, а також умови праці, справедливість у ставленні до працівників шляхом використання однакових підходів та критеріїв.

Також актуальність теми дослідження пов'язана з обраним Україною курсом щодо зближення вітчизняного законодавства з нормами права Європейського Союзу. Адаптація законодавства України до європейських стандартів є важливим складником процесу інтеграції України до Європейського Союзу, що своєю чергою стає пріоритетним напрямом української зовнішньої політики.

Питання оцінювання результатів службової діяльності є багатоаспектним і різностороннім, йому приділялася певна увага в юридичній науці і насамперед у теорії адміністративного права. Зокрема, на рівні дисертаційних досліджень таких науковців, як: Л.Р. Біла-Тіунова, Ю.Р. Битяк, Л.М. Корнута, Г.В. Фоміч, О.М. Стець та ін., а також монографічних досліджень таких учених, як: В.Б. Авер'янов, І.П. Голосніченко, С.Д. Дубенко, С.В. Ківалов, Т.О. Коломоєць, І.М. Пахомов та ін. Водночас можна визначити, що наукові напрацю- вання та теоретичні положення теоретиків стали науково-теоретичним підгрунтям становлення i розвитку як інституту державної служби загалом, так і питань професійного оцінювання зокрема. Отже, подальший розвиток законодавства з питань державної служби, а також адаптація інституту державної служби до стандартів Європейського Союзу, комплексні дослідження питань оцінювання результатів професійної діяльності державних службовців зумовлюють актуальність обраної теми дослідження.

Тому метою статті є з'ясування та аналіз окремих особливостей, що здатні впливати на оцінювання результатів службової діяльності, керуючись новітніми підходами та законодавчими перетвореннями, а також з урахуванням зарубіжної практики. Окрім того, на підставі визначених особливостей формулювання пропозицій щодо удосконалення та розвитку процедури оцінювання результатів службової діяльності державних службовців.

Слід зазначити, що процедура оцінювання у державній службі є одним із дієвих способів управління сферою державної служби, який має суттєвий потенціал для впливу на ефективність та прозорість функціонування всього апарату державної служби, розстановку кадрів, сприяння прозорому добору на керівні посади державної служби виключно висококваліфікованих і професійних осіб, які у майбутньому будуть результативно, ефективно та якісно адмініструвати державну службу, а також виконувати покладені на них професійні завдання та посадові обов'язки. Окрім цього, для України надзвичайно важливим $є$ впровадження ефективного інструментарію оцінювання результатів службової діяльності для державних службовців вищого корпусу державної служби, покликане своєчасно та на належному рівні забезпечувати ефективне та дієве управління апаратом державної служби. Більше того, оцінювання результатів службової діяльності державних службовців має вагоме значення для просування самих державних службовців по службі, тобто на реалізацію їхньої службової кар'єри, що свідчить про актуальність цього етапу проходження державної служби, важливість його теоретичного опрацювання та належного правового регулювання. 
Розглядаючи проблематику нормативного та теоретичного визначення особливостей оцінювання результатів службової діяльності можна виділити два складники цього питання. По-перше, це нормативний складник, що передбачає законодавче визначення порядку та особливостей оцінювання державних службовців. По-друге, це соціальний складник, адже нині, як ніколи раніше, суспільство зацікавлене в наданні якісних державних послуг та очікує професійної, результативної діяльності державних службовців не залежно від політичних впливів чи міркувань $[4$, с. 3]. Тому оцінювання державних службовців має бути важливим інструментом забезпечення об'єктивного контролю за результатами професійної діяльності уповноважених осіб, що висуває конкретні вимоги до забезпечення чіткого зв'язку між плануванням професійного управління, функціонуванням органів влади та державних службовців.

Натепер новий підхід до питання оцінювання державних службовців насамперед визначається профільним нормативним актом у цій сфері Законом «Про державну службу» 2015 р. Зокрема, результати службової діяльності державних службовців щороку підлягають оцінюванню для визначення якості виконання поставлених завдань, а також з метою прийняття рішення щодо преміювання, планування їхньої кар'єри [1, ст. 44]. Саму процедуру проведення оцінювання результатів службової діяльності державних службовців визначає Кабінет Міністрів України. Водночас законодавчо визначено, що керівник державної служби в апараті органу законодавчої та судової влади може проводити оцінювання результатів службової діяльності державних службовців з урахуванням особливостей проходження державної служби в апараті таких органів.

Визначення порядку перевірки та професійної відповідності, як оцінювання результатів службової діяльності, підкреслює не лише практичний характер процедури, але й вказує на основний критерій, який має враховуватися під час оцінки, а саме результативністьслужбовоїдіяльності [4, с. 3].

Оцінювання діяльності державних службовців нині відіграє важливу роль у системі управління людськими ресурсами. Окрім того, оцінювання $\epsilon$ ключовим інструментом для управлінців та керівників державних органів, який дає змогу інформувати та узгоджувати завдання та цілі державного органу із можливостями державних службовців, а також $є$ інструментом перегляду та зміни напряму роботи окремих службовців та оптимізації їх праці [2]. Для самих службовців процес оцінювання $е$ важливим, оскільки зазвичай такий процес пов'язаний із системою заохочень, може визначати рішення щодо просування по службі державного службовці та його преміювання. Такі заохочення є певним мотиваційним поштовхом для серйозного підходу та підготовки до службового оцінювання. Оцінювання результатів службової діяльності є механізмом для підтримки особистого розвитку та вдосконалення діяльності для державного службовця, також слугує свого роду інструментом діагностування для визначення потреб у професійному навчанні та професійному розвитку у тій чи іншій сфері [3, с. 63]. Такий розвиток може стосуватися певних повноважень чи, навпаки, здобуття знань 3 метою їх втілення надалі у практичну діяльність. Професійне оцінювання, безумовно, відкриває можливості відвертого діалогу між державним службовцем, що обіймає конкретну посаду, та безпосереднім керівником щодо якості діяльності, стимулювання праці та підтримки.

Необхідно враховувати, що механізм оцінювання, маючи принципово нове значення та мету, $€$ передусім інструментом, що має використовуватися для пошуку шляхів вдосконалення професійної діяльності, але жодним чином не посилювати функції контролю чи покарання. Оцінювання діяльності державних службовців має відбуватися на основі принципів управління з орієнтацією на досягнення очікуваних результатів. Вимоги результативності, ефективності, прозорості, справедливого оцінювання, професіоналізму, об’єктивності є визначальними для проведення оцінювання. Однією з цілей налагодження дієвого управління професійною діяльністю державних службовців на основі результатів службової діяльності є покращення публічного адміністрування загалом та професійної компетентності державного службовця зокрема. Зазначене знаходить своє вираження в активному управлінні людськими ресурсами, персоналом з точки зору часу, що приділяється обговоренню результатів діяльності, навчанню, наставництву та лідерству, відзначенню та заохоченню постійного вдосконалення та саморозвитку.

Сама процедура оцінювання результатів службової діяльності $€$ потужним інструментом мотивування державних службовців. Обговорення очікуваних результатів службової діяльності, досягнення порозуміння та згоди 3 колегами та керівником державного органу щодо поставлених перед службовцем завдань сприяє мотивації працівників на більш успішну та результативну діяльність. Тому в таких умовах важливо спільно планувати та визначати вимоги щодо результатів службової діяльності у справедливий та прозорий спосіб [3, с. 4]. Прикладом у цьому питанні може бути закордонна практика. Так, майже у всіх країнах Європейського Союзу державні службовці працюють на основі чіткого опису своїх повноважень та функцій, профілів компетенцій та угод щодо виконання конкретних професійних завдань діяльності, саме тому державні службовці 
зацікавлені в адекватному оцінюванні результатів службової діяльності та досягненні очікуваних результатів [5].

Звертаючи увагу на викладені вище особливості сфери оцінювання результатів службової діяльності щодо професійних повноважень та особи державного службовця, можна виділити основні фактори, що здатні впливати на розвиток особистості державного службовця як людини та професіонала. Отже, серед факторів, що впливають на результат оцінювання державних службовців можна визначити такі як:

1) опис конкретних цілей професійної діяльності працівника;

2) обмежена кількість завдань, що дасть можливість визначити пріоритетні напрями діяльності та отримати конкретний результат;

3) з'ясування прямого зв'язку між завданнями та цілями, а також професійними повноваженнями, що визначаються законодавством;

4) деталізація цілей та завдань у процесі активної співпраці державного службовця з керівником;

5) практична значимість встановлених цілей, що спонукає працювати на результат;

6) підтримка керівника на шляху досягнення цілей та під час виконання завдань;

7) очікування конкретного результату та його закріплення;

8) винагорода після досягнення цілей та виконання завдань;

9) значимість досягнення цілей, що може виражатися у призначенні винагороди чи просуванні по службі;

10) стимул державних службовців до професійної освіти, саморозвитку та самоосвіти.

Натепер перевага надається більш спрощеним з технічної точки зору підходам до оцінювання, які переважно спираються на розвиток та зміцнення співпраці, діалогу службовця та його безпосереднього керівника на основі аналізу досягнутих результатів, контексту, потреб сторін для розвитку їх компетентності та нових можливостей. Відповідно, форми для оцінювання стають коротшими та більш простими. При цьому акцентується необхідність і важливість адекватної підготовки тих, хто здійснює оцінювання та кращому поінформуванню всіх учасників процесу та налагодженню їхньої співпраці.

\section{Iimepamypa}

1. Про державну службу : Закон України від 10.12.2015 р. № 889-VIII / Верховна Рада України. URL: https://zakon.rada.gov.ua/laws/show/889-19 (дата звернення: 18.12.2019 р.).

2. Про запобігання корупції : Закон України від 14.10.2014 р. № 1700-VII / Верховна Рада України. URL: http://zakon2.rada.gov.ua/laws/show/1700-18 (дата звернення: 18.12.2019 р.).

3. Корнута Л.М. Розвиток самоосвіти державного службовця як окремого виду підвищення рівня профе- сійної компетентності. Науковий вісник Херсонського державного університету. Серія "Юридичні науки». 2018. Вип. 5. С. 62-64.

4. Проєкт Рекомендацій щодо вдосконалення процедури оцінювання результатів службової діяльності державних службовців. Реформа управління персоналом на державній службі. URL: www.ucs-hrm.org.ua (дата звернення: 18.12.2019 р.).

5. Публічна служба. Зарубіжний досвід та пропозиції для України / за заг. ред. В.П. Тимощука, А.М. Школика. Київ : Конус-Ю, 2007. 735 с. С. 427-454.

\section{Анотація}

Васильківська В. В. Оцінювання результатів службової діяльності: особливості факторів, що впливають на результат. - Стаття.

У статті досліджується питання особливостей оцінювання результатів службової діяльності в Україні. Звертається увага на порядок реалізації процедури оцінювання та визначаються фактори, що впливають на результат проведення процедури оцінювання. Наводиться приклад зарубіжного досвіду в частині проведення процедури оцінювання та аргументуються перспективи удосконалення подальшого законодавчого удосконалення оцінювання державних службовців в Україні.

Зазначається, що процедура оцінювання у державній службі є одним $з$ дієвих способів управління сферою державної служби, який має суттєвий потенціал для впливу на ефективність та прозорість функціонування всього апарату державної служби, розстановку кадрів, сприяння прозорому добору на керівні посади державної служби виключно висококваліфікованих і професійних осіб, які у майбутньому будуть результативно, ефективно та якісно адмініструвати державну службу, а також виконувати покладені на них професійні завдання та посадові обов'язки.

Визначено складники, що виражають особливості оцінювання результатів службової діяльності. Перший складник - це нормативний складник, що передбачає законодавче визначення порядку та особливостей оцінювання державних службовців. Водночас другий складник - це соціальний складник, адже нині, як ніколи раніше, суспільство зацікавлене в наданні якісних державних послуг та очікує професійної, результативної діяльності державних службовців незалежно від політичних впливів чи міркувань. Констатовано, що оцінювання державних службовців має бути важливим інструментом забезпечення об'єктивного контролю за результатами професійної діяльності уповноважених осіб, що висуває конкретні вимоги до забезпечення чіткого зв'язку між плануванням професійного управління, функціонуванням органів влади та державних службовців.

Оцінювання діяльності державних службовців відіграє важливу роль у системі управління людськими ресурсами. Професійне оцінювання $є$ ключовим інструментом для управлінців та керівників державних органів, що дає змогу інформувати та узгоджувати завдання та цілі державного органу з можливостями державних службовців, а також є інструментом перегляду та зміни напряму роботи окремих службовців та оптимізації їх праці.

Водночас для самих службовців процес оцінювання є важливим, оскільки зазвичай такий процес пов'язаний із системою заохочень, може визначати рішення щодо просування по службі державного службовця та його преміювання. Такі заохочення є певним мотиваційним поштовхом для серйозного підходу та підготовки до службового оцінювання. Оцінювання 
результатів службової діяльності є механізмом для підтримки особистого розвитку та вдосконалення діяльності для державного службовця, також слугує свого роду інструментом діагностування для визначення потреб у професійному навчанні та професійному розвитку у тій чи іншій сфері. Такий розвиток може стосуватися певних повноважень чи, навпаки, здобуття знань з метою їх втілення надалі у практичну діяльність. Важливо враховувати, що механізм оцінювання є передусім інструментом, що має використовуватися для пошуку шляхів удосконалення діяльності, а не посилювати функції контролю та покарання. Професійне оцінювання, безумовно, відкриває можливості відвертого діалогу між державним службовцем, що обіймає конкретну посаду, та безпосереднім керівником щодо якості діяльності, стимулювання праці та підтримки. Також у статті визначено сукупність факторів, що впливають на результат оцінювання державних службовців.

Ключові слова: державна служба, оцінювання державних службовців, професійний розвиток, професійні повноваження, фактори розвитку, самоосвіта.

\section{Summary}

Vasylkivska $V . V$. Performance appraisal: features of the factors that influence the outcome. - Article.

The article explores the peculiarities of evaluating the performance of service activities in Ukraine. Attention is paid to the procedure of implementation of the evaluation procedure and the factors that influence the outcome of the evaluation procedure are determined. The example of foreign experience in the evaluation procedure is given and the prospects of improvement of further legislative improvement of the evaluation of civil servants in Ukraine are argued.

It is noted that the civil service evaluation procedure is one of the effective ways of managing the public service sphere, which has a significant potential for influencing the efficiency and transparency of the functioning of the entire civil service apparatus, staffing, facilitating transparent selection of highly professional and highly professional civil servants who will, in the future, effectively, efficiently and qualitatively administer the civil service, as well as fulfill their professional tasks and duties.

The components that express the peculiarities of evaluating the results of service activities are identified. First, it is a regulatory component, that provides for a legislative definition of the procedure and features of the assessment of civil servants. At the same time, the second component is a social component, because today, as never before, society is interested in providing quality public services and expects professional, productive activity of civil servants, regardless of political influences or considerations. It is stated that the assessment of civil servants should be an important tool for ensuring objective control over the results of the professional activities of authorized persons, which puts forward specific requirements for ensuring a clear link between the planning of professional management, the functioning of the authorities and civil servants.

Assessing the performance of civil servants plays an important role in the human resource management system. Professional appraisal is a key tool for managers and heads of state bodies, which allows informing and aligning the tasks and goals of the state body with the capabilities of civil servants, as well as an instrument for reviewing and changing the direction of individual employees and optimizing their work.

At the same time, the evaluation process is important for the employees themselves, as such a process usually involves an incentive system that can determine the decision to promote and reward a civil servant. Such incentives are a motivating impetus for a serious approach and preparation for a job evaluation. Performance appraisal is a mechanism to support personal development and improve performance for the public servant and also serves as a diagnostic tool to identify needs for vocational training and professional development in a particular field. Such developments may relate to certain powers or vice versa to the acquisition of knowledge in order to translate them further into practical activities. It is important to keep in mind that the evaluation mechanism is first and foremost a tool that should be used to find ways to improve performance, not to strengthen the control and punishment functions. Professional evaluation certainly opens up opportunities for an open dialogue between a civil servant holding a specific position and a direct leader on quality of work, incentives and support. The article also identifies a set of factors that influence the outcome of civil servants assessment.

Key words: civil service, evaluation of civil servants, professional development, professional powers, factors of development, self-education. 